\title{
The Administrative State in Poland Before and After the European Union Accession
}

\author{
Dorota Dabek* \\ Jerzy Supernat* \\ https://doi.org/10.31297/hkju.20.1.2
UDK $342.5(438)$

$35.07(438)$
$342.97(438)$ \\ Original scientific paper / izvorni znanstveni rad \\ Received / primljeno: $\quad$ 13.11.2019. \\ Accepted / prihvaćeno: $\quad$ 14. 2. 2020.
}

The article offers a concise study of the gestalt of the Polish administrative state before and after the accession of the Republic of Poland to the European Union in 2004. Pre-accession and post-accession fundamentals in the field of public administration and administrative law are identified and analyzed within the framework of the Europeanization of administrative law and administration in EU member states. The outcome of the process of Europeanization is the operation of the Polish administration and administrative law, not only within the context of the Polish state and Polish law, but increasingly within the su-

* Dorota Dąbek, Professor, Jagiellonian University, Krakow, Poland (redovita profesorica Jagelonskog sveučilišta u Krakovu, Poljska, e-mail: dorotadabek@poczta.onet.pl)

ORICID ID: https:/orcid.org/0000-0001-8460-8272

** Jerzy Supernat, Professor, University of Wrocław, Poland (redoviti profesor Sveučilišta u Wrocławu, Poljska, e-mail: jerzy.supernat@uwr.edu.pl)

ORCID ID: https://orcid.org/0000-0002-4590-0980 
pra-state European administrative framework and European legal space and European public law.

Keywords: state, administration, administrative law, accession, European Union, Europeanization

\section{Introduction}

Surprisingly, the term administrative state is rather unknown and what's more, not welcome in Polish administrative scholarship, not to mention among professional administrators and the general public. The reason for this seems to lie in the negative connotations of the term administrative state arising from its affiliation with the term bureaucratic state; denoting bureaucratic pathologies of the state and its administration. The authors borrowed the term from the book The Administrative State (von Bogdandy, Huber \& Cassese, 2017) where it appears with its proper neutral descriptive meaning. ${ }^{1}$ It is interesting to note that while Cassese (2017, p. 58) ascribes the invention of the term administrative state to the American political scientist D. Waldo (1948), the German state was being described as becoming an administrative state, Verwaltungsstaat, as early as the beginning of the $20^{\text {th }}$ century, whilst its predecessor was called the police state (police being the equivalent of administration), Polizeistaat (Langrod, 2003; Longchamps, 1949), described also as the welfare state, Woblfartsstaat (Bigo, 1932, p. 24). Another state being described as administrative at the beginning of the $20^{\text {th }}$ century was Austria (Wiederin, 2017, p. 126).

The purpose of this text is to examine the gestalt ${ }^{2}$ of the Polish administrative state before and after the accession of the Republic of Poland to the European Union in 2004, within the context of the Europeanization of administrative law and administration in the EU member states. Our research hypothesis is that the accession sped up and strengthened the process of the Europeanization of the administrative state in Poland, which started with the end of socialism in the late 1980s, or even earlier

1 The authors' modest conviction is that this paper and the paper written by J. Supernat (2018) will have the side effect of paving the way for the use of the term administrative state in Poland and for explaining the concept of the administrative state.

${ }^{2}$ Gestalt is another term borrowed by the authors from the book The Administrative State (von Bogdandy et al., 2017). 
under the socialist regime. ${ }^{3}$ The outcome of the process of Europeanization is the operation of the Polish administration and administrative law, not only within the context of the Polish state and Polish law, but increasingly within the supra-state European administrative framework and European legal space and with European public law. To this effect, the article focuses on concepts of state and statehood, the administrative dimensions of Europeanization, the pre and post-accession concept of administration, and finally language, a factor without which neither the practice nor the theory of administration is possible.

\section{State and Statehood}

A state can appear and disappear; it is, as T. Hobbes famously formulated, a Mortal God. ${ }^{4}$ Only a few states have had the privilege of preserving state continuity, having a more or less continuous development. Popular examples are the United Kingdom, Sweden and Switzerland. The list is not an exhaustive one, yet another possible example is Croatia, whose Constitution $^{5}$ in the opening part entitled Historical Foundations, refers to "historical facts and the universally accepted principles governing the contemporary world" that allow to conclude on "the millennial national identity of the Croatian nation and the continuity of its statehood." The history of Poland shows it to be a country deprived of a state (a stateless country or even a colony) for 123 consecutive years (1795-1918), and other countries without or with a low level of statehood throughout their history provide us with the opposite example and a lesson to learn from. With this in mind, a critical question arises: does accession to and membership in the EU, which is a supra-state organization aiming to "create an ever closer union among the peoples of Europe", 6 present a danger to preserving the status of a state?

3 An example of pre-accession Europeanization is the reactivation of the administrative judiciary, which took place in Poland in 1980 in connection with the ratification of the International Covenant on Civil and Political Rights. Still, the role of the Polish judicial review is not comparable to the one in countries free from the experience of a totalitarian system, and deference to administration in the judicial review can be identified practically only in the context of the execution of the European Union law and policies (Kmieciak \& Wegner, 2019, p. 372).

4 Hobbes' metaphor of a state was recently recalled by Biaggini (2017, p. 557).

5 The Constitution of the Republic of Croatia of 22 December 1990.

6 See the preamble and Art. 1(2) of the Treaty on the European Union (TEU), and the preamble to the Treaty on the Functioning of the European Union (TFUE). As the 
An answer to the above question may be based on the four standard elements of the conventional concept of a state: population, territory, government and the capacity to enter into relations with other states (Biaggini, 2017, p. 558). As long as these are preserved, one can maintain that membership in the EU and transferring a significant part of state sovereignty to the EU doesn't conflict with a state's status. In case of the territorial element of the Polish state, the opposite opinion is even justified. One can observe that before accession to the EU Poland was located between Germany and Russia, whilst today Poland is located on the eastern border of the EU. From the geopolitical and geostrategic viewpoints, this is a great change of fundamental importance for the safety of Poland. The reasoning behind not losing state status is strengthened by the fact that having the status of a European state is a necessary condition of membership in the $\mathrm{EU},{ }^{7}$ that transfer of a part of state sovereignty follows the state decision of conferral, ${ }^{8}$ and that being a member state of the EU doesn't eliminate the possibility of being a member of other international organizations.

\section{Europeanization}

Concepts and phenomena, including time and space, are embedded in context. This is also true in the case of the process of Europeanization; the natural consequence of membership in the EU. After the initial focus on the new extra-state (supra-state) institutions, bodies, offices and agencies, came enhanced interest in the EU's actual impact on the member states since the 1990s, called Europeanization. A new impetus to the use of the notion came with the $2004 \mathrm{EU}$ eastern enlargement. But what exactly is to be understood by the notion of Europeanization still remains a bit unclear. Applying the metaphor of the common denominator, it could be summarized that Europeanization is concerned with the influence of the EU on its member states, or with changes in national polity, politics,

process of European integration is confronted with specific local (national) conditions, the impacts of the Europeanization process are far from European unity.

7 See Art. 49 of the Treaty on the European Union.

8 The principle of conferral determines whether the EU enjoys or lacks the competence to act. According to this principle, the European Union may only act where this is provided in the EU Treaties. The Treaties being concluded by the states. The fact that the EU has a legal personality (Art. 47 of the TEU) allows it to conclude international agreements with third countries, i.e. non-member states. Making use of this state-like function, the EU must stay in line with the principle of conferral. 
and policy brought about by the EU. Different perspectives have been applied: some analyses focus on the very process, others focus more on its (formal) outputs and (substantive) outcomes, while still others try to identify the determinants (politico-legal, administrative, economic, socio-cultural, etc.) of the implementation of EU law in the member states (Hofmann \& Türk, 2009). The intertwined notions of the Europeanization of administrative law and the Europeanization of administration are similarly unclear, although one thing may be said without any doubt and that is that their understandings and definitions are obviously linked with the concept of European public law, which grew around the administrative state and brings about a common legal space (von Bogdandy, 2017), as well as with the concepts of the European administrative space (Olsen, 2003; Trondal \& Guy Peters, 2015; Koprić, 2017), and the European administrative system (Bauer \& Trondal, 2015).

The process of Europeanization, including the Europeanization of public (administrative) law, is the essence of the EU, i.e., to establish common policies and legal rules in order to bring member states together (integration through law). As such, Europeanization is close to the notions of unification and harmonization of national legal systems. The idea of public law as a constructive tool of legal unification and the belief that there can be a common law of some sort that is independent of the state, as well as a common legal space, are of critical importance. Regarding the Europeanization of administration (European administrative space/system), it must be observed that in some fields (e.g. economic integration and safety: food safety, transportation safety, etc.) EU institutions, bodies, offices and agencies assume more and more important administrative functions, thus replacing national administrations.

Modern type administration, with administrative law submitting administrative bodies to the rule of law, was born and developed in a state framework in the course of the nineteenth century. ${ }^{9}$ In the first half of the twentieth century, the relationship between administration (and administrative law) and the state used to be, to use a metaphor from a poem for children, like that between Mary and her little lamb; inseparable. However, in the EU this is no longer the case. National administrations function together with the EU administration ${ }^{10}$, whereby the former is undergoing the process of Europeanization. The administrative legal corpus in the EU is not

9 One cannot deny that ancient Rome had a really good administration, but the existence of administrative law in ancient Rome is not generally accepted.

10 See concepts of mixed administration, composite administration, joint administration, network administration, European administrative space, European administrative system, etc. 
a national one, but a European one, embracing EU administrative law and national administrative laws within the framework of European public law. It ought to be stressed that in addition to the vertical exchange going on in both directions between the EU and its member states, the horizontal dimension of European public law is also embraced, which is represented by mimetic processes, convergence, isomorphism, comparative analysis, inspiration, and exchange among the member states. ${ }^{11}$ Moreover, the concept of European public law also includes European comparative legal scholarship that exceeds national borders and breeds common European categories and concepts free from the positive law of any individual member state. Art. 179 (1) of the TFUE foresees achieving "a European research area in which researchers, scientific knowledge and technology circulate freely." 12 In the future, this solution could produce a European scientific (academic) community. However, creating such a community requires a European identity of its members, which is still missing today as the majority of researchers see themselves in relation to their specific national law and national scientific community, whilst European public law and the European common legal space require a European identity. Its accomplishment is not easy because of many reasons that can be summarized as the diversity of national legal cultures, including the diversity of languages (Ongaro \& van Thiel, 2018). The idea of European public law serves well for the building of the European common legal (and administrative) space and for creating the European identity of researchers.

\section{Europeanization of Administrative Law}

The Europeanization of administrative law has many aspects and dimensions. Below are briefly discussed those that seemed to gain momentum after Poland's accession to the EU. They can be grouped under the following headings: sources, cooperation, paradigm (constitutionalization), administrative democracy, scope and depth, and outcomes.

11 A number of (not only) Central and Eastern European (CEE) countries, like Poland and Hungary, could be said to be under a distinct German legal influence; getting inspired and copying German legislation and case law (see Fromont, 2017, p. 595 ff.). Although risky, the notion of intellectual Germanization could be applied here.

12 The European Research Council, together with its executive agency (the European Research Council Executive Agency) occupy a significant position within the European research area. 


\subsection{Sources}

The impact of Europeanization on administrative law in its formal dimension brings about the Europeanization of the sources of administrative law. One can observe a massive inflow of European norms in national administrative laws. These European norms create European administrative law, which is a body of rules and general principles of EU law that constitute the administrative law part in European Union law (the other part is framed directly in primary law and produced by the Court of Justice of the EU). Judgments of the Court from a formal point of view are not sources of EU law, but their impact on EU law is significant in the process of interpretation and application of EU law. In comparison with the judgments of the Polish courts they have a different quality, namely they create law to a much higher extent than the judgments of Polish administrative judges, and as such can be placed between standard judgments, applicable only in a specific case, and precedent judgments.

Penetration of EU norms into domestic legal systems increases in a way that escapes the grasp of the state; secondary law ${ }^{13}$ with doctrines of direct effect and primacy being the best possible example. The scope of the doctrine of direct effect is of critical importance. It is addressed not only to the judicial branch but also to the (national) executive branch, which means that where a provision of EU law has direct effect, it is binding on all the authorities of the member state, that is, not only on the national courts but also on all administrative bodies (administrative direct effect).

\subsection{Cooperation}

The Europeanization of administrative law means that national sources of administrative law have to cooperate with EU sources. Moreover, the latter include both particular texts, Treaties and EU secondary law (special written provisions), and general principles; that is the general principles of EU law applicable in all situations of national implementation of EU policies and rules. ${ }^{14}$ Special provisions and general principles are some-

13 Secondary law takes various forms. Art. 288 of TFUE acknowledges three binding legal instruments: regulations, directives and decisions (and two non-binding instruments: recommendations and opinions), with regulations and decisions having direct effect in the national legal orders, and directives being indirect forms of EU law.

14 The body of principles that constitutes the administrative part in EU law and that is consistent with the principles in national administrative laws allows us to speak about a 
times strongly intertwined, which is exemplified by good administration as being an element of the right to good administration and a principle of good administration..$^{15}$ This example is of significant importance, as good administration can be seen as the administrative law equivalent to the constitutional concept of the community of law proclaimed by the European Court of Justice. ${ }^{16}$

In Poland, ensuring the effective compliance of domestic provisions with EU law is the task of the administrative courts. ${ }^{17}$ In case of the lack of compliance, the courts disregard application of the national law if contrary to EU law, applying instead the EU law directly. In other words, Polish administrative courts are the guardians of proper cooperation between Polish law and Union law (and Union bodies). One example of such courts' custody is the stance of the Polish Supreme Administrative Court (Naczelny Sad Administracyjny - NSA) regarding the right to the return of excise duty. NSA challenged the Polish statutory limitation of categories of individuals entitled to the return of excise duty as not compatible (too restrictive) with Council Directive 2008/118/EC of 16 December 2008 concerning the general arrangements for excise duty, ${ }^{18}$ concluding that the right to the return of excise duty is derived directly from the provisions of the Directive. ${ }^{19}$

In addition, national administrative judges come to be challenged by European judges in the development of administrative law in the European context. In particular, interpretation of EU law by national administrative courts should be based on: the content of EU law, judgments of the Eu-

European model of administrative law. Some lawyers grouped in the Research Network on European Union Administrative Law (ReNEAUL) have argued for a codification of its procedural part (see Craig, Hoffman, Schneider \& Ziller, 2017; Bermann, 2010; Supernat \& Kowalczyk, 2017).

15 Hofmann, Rowe and Türk (2011, p. 190 ff) write in depth on the double status of good administration; that of a fundamental right and, in its wider sense, that of a general principle of EU law under Art. 41 of the Charter of Fundamental Rights of the European Union and Art. 6(1) of the TEU.

${ }^{16}$ Case 294/83 Les Verts vs. Parliament [1986] ECR 1339.

17 Compliance should be ensured in the process of the application of the law, but also in the process of law-making. National legislature cannot pass laws that are not compatible with EU law. Therefore, in case of making law in fields already regulated by Union law, the earlier interpretation of Union law is necessary in order to avoid conflicts between national law and Union law that later have to be resolved in the process of the application of the law. The fields, scope and methods of harmonization of laws of member states in the EU are discussed in depth by Osiejewicz (2016).

18 OJ 2009, L 9/12

19 See for example the verdict of NSA of 23 February 2017, I GSK 1837/15. 
ropean Court of Justice, and judgments of the Court regarding preliminary questions. Narrowing the interpretation of EU law poses a danger for harmony in the functioning of both Union and national laws. Lack of harmony can in turn breed conflicts between Union and national bodies, as well as causing lack of legal certainty and the proper protection of private interests..$^{20}$ One such case is telling here. The Polish Supreme Administrative Court by the decision of 23 February 2016 referred to the Court of Justice of the EU for a preliminary ruling on the interpretation of Directive 2006/112/EC, in so far as it affected the value added tax which is charged on the supply of a building, or parts thereof, and of the land on which it stands. ${ }^{21}$ According to the firm judgment of the Court of Justice of 16 November 2017, concrete provisions of the Directive must be interpreted as precluding a national law. Following this judgement, the Polish administrative courts continued in the line of not applying national provisions that were contrary to Union directives. Their reasoning was as follows: "National provisions and legal practice, judicial or administrative, leading to the diminishing of the effectiveness of community law, depriving the adjudicating court of the ability to do everything that is necessary to set aside national law and being an obstacle (even temporary) to the full effectiveness of community norms, wouldn't be acceptable in the light of requirements flowing from the very nature of community law." ${ }^{22}$ Nota bene, the principle of effectiveness of EU law limits national procedural autonomy, as procedural and organizational provisions of national law cannot make use of the rights granted by EU law too difficult or impossible.

\subsection{Paradigm (Constitutionalization)}

The Europeanization of administrative law is supportive of a fundamental transformation in administrative law. Historically, administrative law treated the individual as a subordinate subject and was mainly an objective law, something reflected in particular in administrative litigations. Today, the concern for human and fundamental rights in $\mathrm{EU} \mathrm{law}^{23}$ leads to a grow-

20 Legal certainty is a critical factor in public (administrative) law, as this law is an interfering one.

21 Case C308/16.

22 The verdict of NSA of 23 November 2017, I FSK 312/16.

23 Lenaerts and Gutiérrez-Fons (2018, p. 107) write that "the very raison d'itre of EU law is inherently linked to the creation of individual rights that are directly enforceable 
ing subjectivism. The result is a subjectivization of administrative litigation, which evolves into a tool for protecting human and fundamental rights (the individual as a holder of rights), and to satisfy the interests affected by the administration, and not only a way of controlling and disciplining it. In the United Kingdom, P. Craig proposed to abandon the perspective whereby the essential function of administrative law was to ensure that the administrative authorities remain within the limits of the powers Parliament has given them; the model of the ultra vires. Instead, he advocated a rights-based approach that focuses more on protecting the rights of individuals. ${ }^{24}$ Such an approach was identified in the ReNEUAL model code for EU administration by the European Ombudsman O'Reilly (2017, p. V) and positively assessed by her: "The law should not become a shield for the administration to hide behind by saying that a particular action is not expressly allowed or forbidden. It is therefore of fundamental importance that ReNEUAL succeeded in avoiding rules that are excessively detailed. The Model Rules do not invite a box ticking approach, nor do they create an obstacle course that inhibits sound judgment or defies common sense".

The fundamental change caused by EU rules and case law in understanding the role of public administration and its attitude towards an individual was brought about inter alia by the Court of Justice of the EU in its judgment of 21 June 2012, in which the Court adjudicated that concrete provisions of the Council Directive 2006/112/EC of 28 November 2006 on the common system of value added $\operatorname{tax}^{25}$ must be interpreted in such a way as to preclude a national practice of tax authorities making the taxable individual responsible for specific tax irregularities being outside his control and, as a result, depriving him the right to deduction from the value added tax. The judgment of the Court of Justice of the EU diametrically changed the line of the case law of Polish administrative courts, transferring the concrete burden of proof from taxpayer to tax authority.

The new paradigm of administrative law is strongly supported by the new value-oriented principles and provisions in constitutional documents. One example is the German Constitution of 1949, which brought about the new role and understanding of the state according to which the state exists for the sake of the individual, not the individual for the sake of the state. Such an understand-

before national courts. For every EU right, there must be a judicial remedy. It is on this founding postulate that the entire EU system of judicial protection is based."

24 Craig's idea is recalled by Auby (2017, p. 626).

25 OJ 2006, L 347/1. 
ing of the relationship between an individual and the state marks a Copernican Revolution in public law (von Bogdandy \& Huber, 2017, p. 218). As such, the administrative principles and provisions in constitutions have brought to the fore the concept of the constitutionalization of administrative law and the constitutional foundations of administrative law (Heuschling, 2017).

The new paradigm of administrative law or the constitutionalization of administrative law is easily identifiable in Poland. Art. 7 of the Polish Constitution $^{26}$ contains the principle of legality according to which "the organs of public authority shall function on the basis of, and within the limits of, the law". The law denoting the whole legal order, especially the Constitution and, today, EU law, including the principles shaped by EU law and EU case law. In practical terms, the principle of legality often means that administrative activity is based directly on constitutional principles and values, especially on Art. 2 of the Constitution declaring that " $\mathrm{t}]$ he Republic of Poland shall be a democratic state ruled by law and implementing the principles of social justice". For example, it is settled case law that in the light of the principle of civic trust in the state and its law (the clause implying that a democratic state is ruled by law), and the principle that obligations of incurring responsibilities and public duties, including the payment of taxes, shall be imposed only by means of statute (Art. 84 and 217 of the Polish Constitution), it is not possible to demand from a taxpayer to incur responsibilities and public duties that are not established by a legislator in a statute, but are shaped by law-applying authorities in the process of extra-linguistic interpretation, e.g. applying systemic or teleological (functional) interpretations.

\subsection{Administrative Democracy}

Among many examples of the Europeanization of administrative law, of special importance and high visibility in Poland (and in other former communist or socialist countries) is the progress of administrative democracy that provides mechanisms for citizen participation in administrative processes. ${ }^{27}$ The mechanisms of administrative democracy are many, although the most common are administrative transparency and procedures for participation, consultation, public debate, and so forth (procedural democracy). The progress is accompanied by the development of various legal

26 The Constitution of the Republic of Poland of 2 April 1997.

27 On administrative democracy in the old Union (as exemplified by France) in the context of participatory and deliberative democracy see Wojtuń 2017, p. 93 ff. 
arrangements that confer new rights (and enhance old ones) on individuals in their dealings with public authorities. The new rights mostly originated in the European sphere where EU law, including the Charter of Fundamental Rights of the EU, provided the systems of administrative law with new guarantees of citizens' rights. ${ }^{28}$ In systems where administrative law is strongly influenced by the constitution and its interpretation by constitutional judges,$^{29}$ the movement towards administrative democracy has naturally been pushed forward together with that of constitutionalization.

Administrative (procedural) democracy may be assessed as only being a complement to political mass, and participatory democracy as being a real democracy where citizens are subjects of political decisions. Nonetheless, it would be a great mistake to diminish its significance for protecting citizens' rights and interests: a subjective right without a procedural provision is a phantom and doesn't deserve to be named as such, it can in fact be considered a misnomer. In conclusion, one can add that the concept of administrative democracy is close to the concept of a third generation administrative procedure as presented by Barnes (2010), which features such innovations as more effective forms of participation, more diversity and decentralization, fostering deliberative arenas, permitting more flexibility, mutual learning and information gathering, and monitoring.

\subsection{Scope and Depth}

Not only are legal texts open to the process of the Europeanization of administrative law, but elusive elements such as concepts, principles, approaches, notions, methods, reasoning styles, legal thinking, as well as legal scholarship are being Europeanized as well (Bobek, 2017, p. 633). One example of this deeper level of Europeanization is the principle of proportionality, being an Europeanized way of thinking and reasoning in law (Tridimas, 2018).

A deeper level of Europeanization is of profound importance as the reality in some countries teaches us that adopting laws and regulations is something different, sometimes even worlds apart, from embracing their

28 Another European contributor is the European Convention of Human Rights.

29 The German and Spanish systems include typical examples of a strong constitutional basis to administrative law in terms of the number of constitutional provisions on administrative matters and the level of development of constitutional review (constitutional litigations). 
spirit and true meaning. Sometimes different meanings are ascribed even to such basic notions as law, code, statute, legal interest and justice. In such situations it should be obvious that accession to the EU requires new competences from national lawyers and the introduction of a broad interpretation field, which means applying a systemic interpretation of the law in the context of the Constitution and EU law, including the principles shaped by Union law and Union case law.

\subsection{Outcomes}

The contemporary changes in administrative law are crucial ones. They tend to profoundly disrupt the legal structure of the administration, the requirements that are imposed on the administration, the concept of the relationship between the administration and the law, as well as between the administration and an individual, and between the administration and society, etc. In doing so, they create the need for theoretical adaptations. Here and there, a theoretical endeavour has been undertaken in scientific discussions, which are now becoming less national in their search for new paradigms capable of accounting for the current reality of administrative law in Europe, although the main paradigm of contemporary legal thinking is still that legal systems are primarily national systems of law. This proposition is prevailing at least in the field of administrative law.

Three outcomes of the Europeanization of administrative law seem to be of special significance. Firstly, the study of national administrative law itself is not enough, especially when focused on case law, as EU administrative law is mainly due to the activities of the Court of Justice of the EU. Therefore, some doctrines try to comprehensively review their theory around this concern. In Poland, a treaty on judge-made law in Polish administrative law (Dąbek, 2010) is a telling example. The new textbook on administrative law with significant parts devoted to European integration and EU law (being mostly administrative law) (Jagielski \& Wierzbowski, 2019), and the textbook on regulatory law with a strong European backdrop (Lipowicz, 2017) are worthy of recalling here as well.

The most ambitious scientific efforts move directly into the European level as the core of thinking about administrative law. In Poland, two Congresses of Administrative Law (one held in Poznan in 2004 and the other in Szczecin in 2014) were devoted to the Europeanization of Polish administrative law (Janku, Leoński, Szewczyk, Waligórski \& Wojtczak, 2005), and the tenth anniversary of the Polish accession to the EU and its 
consequences for administrative law and public administration (Sługocki, 2014). Another example of moving squarely into the European level is the first Polish textbook on administrative law of the European Union (Grzeszczak \& Szczerba-Zawada 2016).

Thirdly, the European theory of administrative law includes connections between the administrative law of the EU and national administrative laws, and the influence that the first exercises on the latter. The vision of European administrative law that includes connections with national administrative laws and the influence exerted on them holds the conviction that "in the future, national administrative laws will be mainly considered an implementation tool for EU rules and policies" (Auby, 2017, p. 622). From the Polish perspective, this prediction seems to go too far.

\section{The Concept (Definition) of Public Administration}

In relation to the national definition of legal notions under the influence of EU law, J.-B. Auby and L. Azoulai distinguish three types of context-dependent reactions: clarification, transformation and addition to the previously existing notion. ${ }^{30}$ Here it is noteworthy that Poland's accession to the European Union has undermined the classic academic definition of public administration framed by Polish late eminent academic Boc. ${ }^{31}$ His definition of public administration, after translating it into English, is as follows: "Public administration means satisfying collective and individual needs of citizens, arising from their living together in communities, by a state and its dependent bodies (central administration and local administration), as well as - within the framework of conferral - by local government bodies (local authorities) (Boć, 2010, p. 15)".

After Poland's accession to the EU this definition has become partly obsolete and can lead to weakening the idea of European integration and the European administrative space (system). Therefore, the concept of public administration must be reconstructed (transformation and addition are necessary) based on the new administrative reality in Europe and Poland.

30 Their observation recalls that of M. Bobek (2017, p. 649).

${ }^{31}$ In the Polish original version: "Administracja publiczna jest to przejęte przez państwo $i$ realizowane przez jego zawiste organy, a także przez organy samorzadu terytorialnego zaspokajanie zbiorowych $i$ indywidualnych potrzeb obywateli, wynikajacych ze wspótżycia ludzi w społecznościach" (Boć, 2010, p. 15). 
Mostly, the definition should say that public administration is not only a state phenomenon but also a supra-state one. Such an addition will allow to link administrative law not only with the administration of the state, but also with the administration of the extra-state (supra-state) organizations. Therefore, the post-accession enlarged definition of public administration, based on Jan Boć's pre-accession one, could be as follows: "Public administration means satisfying collective and individual needs of people, arising from their living together in communities, by a state and its dependent bodies (central administration and local administration), its independent bodies (decentralized administrative agencies), as well as - within the framework of conferral - by local government bodies (local authorities) and bodies of extra-state (supra-state) organizations." (Authors, based on Boć, 2010, p. 15).

Three remarks may and should be framed in connection with the above proposal. Firstly, the proposed post-accession enlarged definition of public administration departs from the traditional view that administration belongs to states or national governments, that legal systems are national systems of law, that administrative law is a product of the state and is a part of national law, and that there cannot be a space for administration and administrative law beyond the state. The extra-state (supra-state) European Union with its administration and administrative law conflicts with such a traditional view and makes it archaic. The state and state administration are no longer absolute protagonists.

Secondly, the definition is a definition, not a theory of a concept, and as such cannot embrace too many constitutive elements, but only a few critical ones. With this in mind we have decided not to fill it with principles other than the principle of conferral, namely the principles of subsidiarity and proportionality, not to mention the principles of democracy, decentralization and the rule of law. Nevertheless, it must be said that principles of subsidiarity and proportionality determine the conditions under which, and the way in which, EU and state competences may be exercised. Therefore, they are so strongly intertwined with the principle of conferral that their meticulous analysis in extra and intra state administrative relations is a necessary condition for the full explanation of the concept of public administration. Here it suffices to say that in extra state relations, the principle of conferral deals with the existence of EU competence to regulate a field, the principle of proportionality addresses the intensity of EU action and seeks to protect member states against the expanding competence of the $\mathrm{EU}^{32}$,

32 The principle of proportionality has acquired particular prominence in recent years as part of a fundamental rights enquiry and become a key instrument of judicial methodol- 
and the principle of subsidiarity regulates the exercise of EU competence by setting a functional criteria to decide whether the EU, or rather the states, should act in a given field (Fabbrini, 2018, p. 221 ff.).

Thirdly, offering a post-accession enlarged definition of public administration, embracing extra-state (supra-state) administration, we were inspired by Longchamps' (1949) scientific theory of public administration and his approach to defining and analyzing (describing) public administration (Longchamps, 1949). The author proposed a universal extra-state approach to defining public administration outside the confines of time, polity and even law (at least in the first phase of framing a definition), concluding that the prevailing way of defining public administration within the framework of the state is too narrow. The approach suggested by him (as early as 1949), produces the definition of public administration of general capacity, which allows to locate within its borders and within the research field of administrative science any administration from the past and the future, including the extra-state administration; in a concrete example, the EU administration.

\section{The Language of Public Administration}

Ongaro and van Thiel (2018, p. 62) observe that "[l]anguage shapes thought, and language diversity - a major trait of cultural diversity - is a key feature of public administration, public management and public policy in Europe". Language diversity in the EU with twenty-four official languages is an undeniable fact. One consequence is that Polish administrative courts, when interpreting EU law, have to take into account different language versions of Union legal texts. ${ }^{33}$ Also, one undeniable fact is that, among EU languages, the English language occupies a special place: it is not only the main language in Ireland and (with regards to Brexit) the United Kingdom, but the contemporary lingua franca and

ogy. Its formalization in the Charter of Fundamental Rights of the EU is of importance here. Art. 52(1) of the Charter reads: "Any limitation on the exercise of the rights and freedoms recognized by this Charter must be provided for by law and respect the essence of those rights and freedoms. Subject to the principle of proportionality, limitations may be made only if they are necessary and genuinely meet objectives of general interest recognized by the Union or the need to protect the rights and freedoms of others". For more on the principle of proportionality see Tridimas (2018, p. $243 \mathrm{ff}$ ).

33 See for example the judgment of NSA of 22 November 2016, II GSK 2443/16. 
the European (and global) vehicle of international discourse on administration. The impact of the English language on public administration and administrative law in Poland after the accession has increased to an unprecedented degree. It suffices to point out that while many crucial English terms are used in the Polish public administration community (by scholars and practitioners) in their original versions (e.g. stakeholders, leadership, governance, agenda, benchmarking, etc.), others have been translated or replaced by their Polish equivalents (one rather funny example is: change agent - agent zmiany), and still others have been tamed and undergone the process of Polonization, with better or worse results: agencification - agencyfikacja, adjudication - adiudykacja, departamentalization - departamentalizacja, digitalization - digitalizacja, discretionary - dyskrecjonalny, evaluation - ewaluacja, implementation - implementacja, cancellation - kancelacja, coercion - koercja, profusion - profuzja, etc. Supernat (2005, p. 183 ff.) lists many more examples of English Polish newspeak. The significance of the English language for Polish administrative law is visible not only in terms of separate words, but also in their collocations, i.e. texts (documents) and books in the administrative domain. What should be stressed here is that next to the translations from English into Polish, there are more and more Polish legal texts and books in English, as well as two languages published in one (bilingual) volume (Polish - English), or in two volumes (one in the Polish version and the other with the English verbatim). A good example of a book in English, published in 2005 to meet the increased interest in Polish law after our accession to the EU, is Outline of Polish Constitutional Law by Banaszak (2005). Two recent examples are the bilingual publication of the Code of Administrative Proceedings (Bińkowska, Chełchowski, Gumola, Kopik \& Walawender, 2017) and the book available in Polish and English by Jagiellonian University Academics on the Integrity of Administrative Law from the Polish Perspective (Zimmermann, 2019a; Zimmermann, 2019b.). The latter is of special relevance, as the issue of the integrity of law is of crucial importance in a state that is a member of the European supra-state organization with its independent legal order ${ }^{34}$ being a source of the Europeanization processes.

34 In the verdict of 23 April 1986, C-294/83, Les Verts vs. Parliament, EU:C:1986:166, p. 23, the European Court of Justice declared that the Rome Treaty was not an ordinary international treaty, but a constitutional treaty, which, like national constitutions, contains a formal base for an independent legal order. This new legal order is an integral part of national legal orders, and national courts are required to apply it. 


\section{Administrative State}

In the opening part of the text we framed an opinion that membership in the EU doesn't eliminate the state status of the member states. Nevertheless, accession to and membership in the EU supra-state organization brings about processes of Europeanization that change the gestalt of member states, including their constitutional and administrative fabric; public administration and administrative law. The administrative outcomes and changes are obvious as the state, and especially the contemporary state, is objectively and subjectively an administrative edifice (from the citizen's perspective, the state manifests itself as a patchwork of administrative institutions, bodies, offices and agencies). As Cassese (2017, p. 58) succinctly observed: "Where there is a state, there is an administrative system, and vice versa". 35

The administration (as a function and an organization) being part and parcel of the state, represents the core shaping and shaped element of each state. Furthermore, the development of a modern administration is closely connected with the emergence and development of the modern state. The relations among the administration and other key actors within the state (government, parliament and judiciary) represent significant features of each state. ${ }^{36}$ The same may be said about the relations between administration (the central administration) and local government, as well as about the relations between administration (the central administration) and decentralized independent administrative regulatory agencies. The fact that administrative functions and tasks are carried out not only by a hierarchical central administration, but also by actors outside the central administration and independent agencies, denotes that the administration, in the sense of a comprehensive all-embracing uniform apparatus, no longer exists. Instead of an administration, we have a better or less organized complex system of administration. Poland, as an administrative state, is of course no exception. According to Art. 3 of the Constitution "Poland is a unitary state" but nowadays, especially after the accession, the reality is a bit more complex: Poland is a unitary state without unitary

35 Characterizing Britain as a "stateless society" (Loughlin, 2017, pp. 452-453) was justified inter alia by lack of a hierarchical and undifferentiated concept of administration and a system of administrative law.

36 The distance between administration and government differs from one state to another. In Poland, the Government (the Council of Ministers) is regarded as the top administrative organ and a part of the public administration (Pawłowski, 2011, p. 249). 
administration. ${ }^{37}$ It should be recalled here that the previous principle of democratic centralism has been replaced by the principle of decentralization, while the local administration (with the exception of governors in regions) has been replaced by local government (post-war Poland didn't have a local government for forty years, from 1950 to 1990). This fundamental democratic change was anchored in our Constitution of 1997 based, inter alia, on the principle of decentralization of public power ${ }^{38}$ and the principle of subsidiarity, aiming to strengthen the power of citizens and their communities. ${ }^{39}$

The contemporary complexity of the administrative state leads to the conclusion that anyone interested in the impact of the EU and the process of Europeanization (and similar phenomena such as internationalization and globalization) on the state and in the concept of statehood ${ }^{40}$ should examine administration in its connection to and intersection with other key actors within the state, or in other words, should examine the gestalt of the administrative state and its legal regime. The latter is of considerable importance, as the majority of contemporary states are, at least nominally according to their constitutional charters, states of law (Davis, Richter \& Saunders, 2015) ${ }^{41}$ Furthermore, it is needless to say that the $\mathrm{EU}$ is also a legal organization ${ }^{42}$ based on a set of fundamental principles

37 The lack of unitary administration is typical for decentralized unitary states, and especially strong in states with regions (e.g. Italy) and autonomous communities (e.g. Spain) as well as implementing the principle of devolution (political decentralization) - e.g. the United Kingdom.

38 Art. 15 of the Constitution of the Republic of Poland.

39 The principle of subsidiarity is inserted into the Preamble to the Constitution of the Republic of Poland.

40 The transformation of state and administration is in no way a new phenomenon. It is as old as the very state and its administration.

41 The image of administration provided by national constitutions is generally limited and the richness of its functions hardly reflected in the constitutional texts. Nota bene constitutions don't provide a comprehensive picture of the ideal of good administration either. The same may be said about the right to good administration anchored in Art. 41 of the Charter of Fundamental Rights of the EU that today has the same legal value as the Treaties (Art. 6 of the TEU), being "the constitution" of the EU. Art. 41 of the Charter contains only provisions aiming to guarantee procedural fairness, but doesn't offer the full definition and description of good administration.

42 Jacobs (2018, p. VIII) sees the specific characteristics feature of the EU in the fact that "the European Union is based exclusively on law, not on power". 
and values (community of values) including the rule of law ${ }^{43}$ (community of law). The rule of law, together with other principles and values listed in Art. 2 of the TEU, is a common denominator for the EU and its member states. Consequently, the EU is not an ordinary international organization, but an organization of integration with a supra-state legal order of the EU and legal orders of the member states. ${ }^{44}$ In these circumstances, the influence of the EU and the process of Europeanization is realized via law (mostly administrative law), bringing as a result the convergence and harmonization of state legal regimes (mostly administrative ones). In other words, administrative law is a major instrument of the rule of law and Europeanization. One should notice here that the process of Europeanization concerns both the content of each fundamental branch of administrative law: substantive (or sector specific) administrative law (Lipowicz, 2017), procedural administrative law (Wilbrandt-Gotowicz, 2018; De Ambrosis Vigna \& Kijowski, 2018), and organizational (systemic) administrative law ${ }^{45}$, and the application of their rules and provisions. ${ }^{46}$ One final remark regards the changes in organizational administrative law, which mean changes in administrative structures that breed the common administrative European space (system) (Bauer \& Trondal, 2015; Trondal

43 See Preamble and Art. 2 of the TEU. The principle of the rule of law in EU law and in Polish law, as well as in the legal systems of several member states has two aspects: first, the submission of official actions to the legal rules and procedures, and secondly, the requirement of a legal basis for action. Art. 7 of the Constitution of the Republic of Poland reads: "The organs of public authority shall function on the basis of, and within the limits of, the law". Despite the similarity there is also a difference here: in EU law, being a developing legal order, case law needs to flash out limits of public power to a much greater extent than within the legal orders of member states with a highly positivist tradition of legislative guidance of public power.

44 The law of the European Union, the laws of European states, and the European Convention on Human Rights are parts of the new emerging public law: European public law (von Bogdandy, 2017, p. 1 ff.).

45 An example is the movement towards decentralization considered, inter alia, as a condition of good state, good governance and good administration. Another example is establishing independent administrative regulatory agencies.

46 The external limits of pro-directive interpretation are derived from the EU law and case law of the Court of Justice of the EU (Kamiński, 2018). The author concludes that the internal domestic contra legem limit (contra legem prohibition) is shaped and modified by EU rules of interpretation. Therefore, "the EU rules of interpretation shaping and confining the domestic interpretative methods establish a new "hybrid methodology" for consistent interpretation" (Kamiński, 2018, p. 23). According to Art. 19(1) of the TEU, the Court of Justice of the European Union "shall ensure that in the interpretation and application of the Treaties the law is observed". This mighty provision allows to unequivocally state that the EU has been established as an organization of law and integration (integration through law). 
\& Guy Peters, 2015), which in turn is of critical importance as the EU relies on national administrations for the implementation of EU law and policies (so called indirect administrative implementation).

\section{Conclusion}

The observations and positions regarding the Polish administrative state before and after accession to the EU allow for three concluding remarks.

Firstly, accession and Europeanization contributed to fundamentally changing the view of administrative law: from a law for administration to a law for society and the individual. Not a source of power and coercion, ${ }^{47}$ but rather an instrument of policy and protection of the public interest and individual rights. The establishment and preservation of a just balance is a difficult task that requires the involvement and cooperation of all branches of the government: legislative, judicial and executive; and in the multilevel EU, on two fundamental levels: the European and the national one. However, administrative law is not limited to a law that protects individuals against the administration, it is also the law of state regulation and governance. This dualism supports the conclusion that the rule of law in administrative law concerns steering the administration toward the pursuit of public interest and protecting private individuals (their rights and legitimate interests) against the administration. ${ }^{48}$

Secondly, administrative law is one component of public law, the other (leaving aside criminal law) is constitutional law. Based on the socialist tradition, legal scholarship and legal education in Poland still draw a line between constitutional law and administrative law. However, an administrative law without constitutional grounding and penetration is no longer conceivable in terms of positive law. The process of the constitutionaliza-

47 The total removal of coercion from a state or administrative activity is difficult to imagine. At least not in the too near future. The legitimate use of coercion in executing laws is so critical for a state and society that it is sometimes even anchored in constitutions. One such example is Art. C(3) of the Fundamental Law of Hungry of the $25^{\text {th }}$ of April 2011, which reads: "The State shall have the right to use coercion in order to enforce the Fundamental Law and legal regulations".

48 M. Fromont (2017, p. 599) has a strong preference regarding the essence of administrative law in free democratic states and, accordingly, the fundamental task of lawyers: "the task of every jurist is to work comprehensively towards the realization of the protection of the citizen. Besides that, administrative efficiency is an important issue; however, this cannot lead to a disregard of the central concern - the protection of freedom". 
tion of administrative law seems to be more and more important in and for the EU. One of the critical issues here is the question of the constitution's direct effect. The problem of EU law is that in the absence of a clear constitutional authority (and coercive mechanisms), it is compliance that fuels normativity. The assumed acceptance of EU law in member states has become part of the normative narration of what EU law actually is. The critical question is of course, what degree of national non-compliance are the EU legal order and EU institutions ready to accept.

Thirdly, the administration has mostly been conceived of as a hierarchically structured entity (unity, monolith, etc.), and as the administration of the state. Today, the administration is viewed as a more or less well-coordinated framework. Such a picture continues to gather momentum with the process of Europeanization and the phenomenon of de-nationalization brought by it. Consequently, Polish administration takes place not only within the context of the Polish state and Polish law, but increasingly in the extra-state (supra-state) European framework, and Polish administrative law in the European legal space evolves from a branch of state public law to a branch of European public law.

\section{References}

Auby, J.-B. (2017). The transformation of the administrative state and administrative law. In A. von Bogdandy, P.M. Huber \& S. Cassese (Eds.) The Max Planck Handbooks in European Public Law Volume I: The Administrative State (pp. 601-630). Oxford, United Kingdom: Oxford University Press. https:// doi.org/10.7590/187479818x15481611819912

Banaszak, B. (2005). Outline of Polish Constitutional Law. Wrocław, Poland: Wydawnictwo Uniwersytetu Wrocławskiego.

Barnes, J., (2010). Towards a third generation of administrative procedure. In S. Ross-Ackerman \& P.L. Lindseth (Eds.) Comparative Administrative Law (pp. 336-356). Cheltenham, United Kingdom: Edward Elgar. https://doi. org/10.4337/9781849808101.00030

Bauer, M. W., \& Trondal, J. (2015). The administrative system of the European Union. In M.W. Bauer \& J. Trondal (Eds.) The Palgrave Handbook of the European Administrative System (pp. 1-28). Basingstoke, United Kingdom: Palgrave Macmillan. https://doi.org/10.1057/9781137339898_1

Bermann, G.A. (2010). A restatement of European administrative law: Problems and prospects. In S. Ross-Ackerman \& P.L. Lindseth (Eds.) Comparative Administrative Law (pp. 595-605). Cheltenham, United Kingdom: Edward Elgar. https://doi.org/10.4337/9781849808101.00048 
Biaggini, G. (2017). Legal conceptions of statehood. In A. von Bogdandy, P.M. Huber \& S. Cassese (Eds.) The Max Planck Handbooks in European Public Law Volume I: The Administrative State (pp. 557-578). Oxford, United Kingdom: Oxford University Press. https://doi.org/10.1093/law/9780198726401.003.0015

Bigo, T. (1932). Prawo administracyjne. Część ogólna [Administrative Law. General Part]. Lwów, Poland: Wyd. J. Rodkowski.

Bińkowska, M., Chełchowski, A., Gumola, P., Kopik, B., \& Walawender, R.A. (2017). Kodeks postepowania administracyjnego [The Code of Administrative Procedure]. Warszawa, Poland: C.H.Beck.

Bobek, M. (2017). Europeanization of public law. In A. von Bogdandy, P.M. Huber \& S. Cassese (Eds.) The Max Planck Handbooks in European Public Law Volume I: The Administrative State (pp. 631-674). Oxford, United Kingdom: Oxford University Press. https://doi.org/10.7590/187479818x15481611819912

Boć, J. (2010). Pojęcie administracji [Concept of Administration]. In J. Boć (Ed.) Prawo administracyjne [Administrative Law]. Wrocław, Poland: Kolonia Limited.

Cassese, S. (2017). The administrative state in Europe. In A. von Bogdandy, P.M. Huber \& S. Cassese (Eds.) The Max Planck Handbooks in European Public Law Volume I: The Administrative State (pp.57-97). Oxford, United Kingdom: Oxford University Press. https://doi.org/10.7590/187479818x15481611819912

Craig, P., Hofmann, H. C. H., Schneider, J.-P., Ziller, J. (Eds.) (2017). ReNEUAL Model Rules on EU Administrative Procedure. Oxford, United Kingdom: Oxford University Press.

Dąbek, D. (2010). Prawo sędziowskie w polskim prawie administracyjnym [JudgeMade Law in Polish Administrative Law]. Warszawa, Poland: Wolters Kluwer.

Davis, D., Richter, A., \& Saunders, C. (Eds.) (2015). An Inquiry into the Existence of Global Values. Through the Lens of Comparative Constitutional Law. Oxford, United Kingdom: Hart Publishing.

De Ambrosis Vigna, A., \& D.R. Kijowski, D.R. (2018). The Principle of legitimate expectation and the protection of trust in Polish administrative law. Białostockie Studia Prawnicze. Białystok Legal Studies, 23(2), 39-52. https://doi. org/10.15290/bsp.2018.23.02.03

Fabbrini, F. (2018). The principle of subsidiarity. In R. Schütze \& T. Tridimas (Eds.) Oxford Principles of European Union law: Volume I: The European Union Legal Order (pp. 221-242). Oxford, United Kingdom: Oxford University Press.

Fromont, M. (2017). A typology of administrative law in Europe. In A. von Bogdandy, P.M. Huber \& S. Cassese (Eds.) The Max Planck Handbooks in European Public Law Volume I: The Administrative State, (pp. 579-600). Oxford, United Kingdom: Oxford University Press. https://doi.org/10.7590/1874798 $18 \times 15481611819912$

Grzeszczak, R., \& Szczerba-Zawada, A. (Eds.) (2016). Prawo administracyjne Unii Europejskiej [Administrative Law of the European Union]. Warszawa, Poland: EuroPrawo.

Heuschling, L. (2017). The complex relations between administrative and constitutional law: A comparative and historical analysis. In A. von Bogdandy, P.M. 
Huber \& S. Cassese (Eds.) The Max Planck Handbooks in European Public Law Volume I: The Administrative State (pp. 493-556). Oxford, United Kingdom: Oxford University Press. https://doi.org/10.1093/law/9780198726401.003.0014

Hofmann, C.H., \& Türk, A.H. (Eds.) (2009). Legal Challenges in EU Administrative Law. Towards an Integrated Administration. Cheltenham, United Kingdom: Edward Elgar.

Hofmann, H.C.H, Rowe, G.C. and Türk A. H. (Eds.) (2011). Administrative Law and Policy of the European Union. Oxford, United Kingdom: Oxford University Press.

Jacobs, F.G. (2018). Foreword. In R. Schütze \& T. Tridimas (Eds.) Oxford Principles of European Union law: Volume I: The European Union Legal Order (pp. VII-VIII). Oxford, United Kingdom: Oxford University Press.

Jagielski, J., \& Wierzbowski, M. (Eds.) (2019). Prawo administracyine [Administrative Law]. Warszawa, Poland: Wolters Kluwer.

Janku, Z., Leoński, Z., Szewczyk, M., Waligórski, M., Wojtczak, K. (Eds.) (2005). Europeizacja polskiego prawa administracyjnego [Europeanization of Polish Administrative Law]. Wrocław, Poland: Kolonia Limited.

Kamiński, M. (2018). Internal and external limits of the principle of consistent interpretation of domestic law with the directives of the European Union and their relevance for the adjudication of administrative courts. Biatostockie Studia Prawnicze. Biatystok Legal Studies, 23(2), 9-24. https://doi.org/10.15290/ bsp.2018.23.02.01

Kmieciak, Z., \& Wegner, J. (2019). Deference to the public administration in judicial review: A Polish perspective. In G. Zhu (Ed.) Deference to the Administration in Judicial Review. Comparative Perspectives (pp. 363-377). Hamburg, Germany: Springer. https://doi.org/10.1007/978-3-030-31539-9_16

Koprić, I. (2017). European administrative space - myth, reality and hopes. In I. Koprić \& P. Kovač (Eds.) European Administrative Space: Spreading Standards, Building Capacities (pp. 31-54). Bratislava, Slovakia: NISPAcee Press.

Langrod, J.S. (2003). Instytucje prawa administracyjnego [Institutions of Administrative Law]. Kraków, Poland: Zakamycze.

Lenaerts, K., Gutiérrez-Fons, J.A. (2018). A constitutional perspective. In R. Schütze \& T. Tridimas (Eds.) Oxford Principles of European Union Law: Volume I: The European Union Legal Order (pp. 103-141). Oxford, United Kingdom: Oxford University Press.

Lipowicz, I. (Ed.) (2017). Instytucje materialnego prawa administracyjnego. Przeglad regulacji [Institutions of Substantive Administrative Law. Review of Regulations]. Warszawa, Poland: UKSW.

Longchamps, F. (1949). Założenia nauki administracji [Assumptions of Administrative Science]. Wrocław, Poland: Wrocławskie Towarzystwo Naukowe.

Loughlin, M. (2017). Evolution and gestalt of the state in the United Kingdom. In A. von Bogdandy, P.M. Huber \& S. Cassese (eds.) The Max Planck Handbooks in European Public Law Volume I: The Administrative State (pp. 451-492). Oxford, United Kingdom: Oxford University Press. https://doi.org/10.1093/ law/9780198726401.003.0013 
Olsen, J. P. (2003). Towards a European administrative space? Journal of European Public Policy, 10(4), 506-531. https://doi.org/10.1080/1350176032000101244

Ongaro, E., \& van Thiel, S. (2018). Languages and public administration in Europe. In E. Ongaro \& S. van Thiel (Eds.) The Palgrave Handbook of Public Administration and Management in Europe, Vol. 1, (pp. 61-100). London, United Kingdom: Palgrave Macmillan. https://doi.org/10.1057/978-1-137-55269-3_4

O'Reilly, E. (2017). Foreword by the European Ombudsman. In P. Craig, H.C.H. Hofmann. J.-P. Schneider \& J. Ziller (Eds.) ReNEUAL Model Rules on EU Administrative Procedure (p. V). Oxford, United Kingdom: Oxford University Press.

Osiejewicz, J. (2016). Harmonizacja prawa panstw cztonkowskich Unii Europejskiej [Harmonization of Laws of the Member States of the European Union]. Warszawa, Poland: C. H. Beck.

Pawłowski, S. (2011). Administrative law. In W. Dajczak, A.J. Szwarc \& P. Wileński (Eds.) Handbook of Polish Law (pp. 243-270). Warszawa, Poland: ParkPrawo.

Sługocki, J. (Ed.) (2014). Dziesięć lat polskich doświadczeń w Unii Europejskiej. Problemy administracyjnoprawne [Ten Years of Polish Experience in the European Union. Administrative Legal Problems]. Wrocław, Poland: Presscom.

Supernat, J. (2005). Zarzadzanie [Management]. Wrocław, Poland: Kolonia Limited.

Supernat, J. (2018). Administrative state in comparative perspective. In D. Cendrowicz \& A. Chrisidu-Budnik (Eds.), Comparative Perspectives for Public Administration and Administrative Law (pp. 25-34). Wrocław, Poland: University of Wrocław. https://doi.org/10.2478/wrlae-2013-0023

Supernat, J., \& Kowalczyk, B. (Eds.) (2017). Kodeks postępowania administracji Unii Europejskiej [Code of Proceedings of EU Administration]. Warszawa, Poland: EuroPrawo.

Tridimas, T. (2018). The principle of proportionality. In R. Schütze \& T. Tridimas (Eds.) Oxford Principles of European Union Law: Volume I: The European Union Legal Order (pp. 243-264). Oxford, United Kingdom: Oxford University Press.

Trondal, J., \& Guy Peters, B. (2015). A conceptual account of the European administrative space. In M.W. Bauer \& J. Trondal (Eds.) The Palgrave Handbook of the European Administrative System (pp. 79-92). Basingstoke, United Kingdom: Palgrave Macmillan. https://doi.org/10.1057/9781137339898_5

Von Bogdandy, A. (2017). The idea of public law today. In A. von Bogdandy, P.M. Huber \& S. Cassese (Eds.) The Max Planck Handbooks in European Public Law Volume I: The Administrative State (pp. 1-29). Oxford, United Kingdom: Oxford University Press. https://doi.org/10.7590/187479818x15481611819912

Von Bogdandy, A., \& Huber, P.M. (2017). Evolution and gestalt of the German state. In A. von Bogdandy, P.M. Huber \& S. Cassese (Eds.) The Max Planck Handbooks in European Public Law Volume I: The Administrative State (pp. 196- 
236). Oxford, United Kingdom: Oxford University Press. https://doi.org/10.7 590/187479818x15481611819912

Von Bogdandy, A., Huber, P.M., \& Cassese, S. (Eds.) (2017). The Max Planck Handbooks in European Public Law Volume I: The Administrative State. Oxford, United Kingdom: Oxford University Press. https://doi.org/10.7590/1874798 $18 \times 15481611819912$

Waldo, D. (1948). The Administrative State: A study of the Political Theory of American Public Administration. New York, USA: The Ronald Press Company.

Wiederin, E. (2017). Evolution and gestalt of the Austrian state. In A. von Bogdandy, P.M. Huber \& S. Cassese (Eds.) The Max Planck Handbooks in European Public Law Volume I: The Administrative State (pp. 125-164). Oxford, United Kingdom: Oxford University Press. https://doi.org/10.7590/1874798 $18 \times 15481611819912$

Wilbrandt-Gotowicz, M. (2018). Europeanisation of administrative proceedings law. Opportunities and risks. Białostockie Studia Prawnicze. Biatystok Legal Studies, 23(2), 25-38. https://doi.org/10.15290/bsp.2018.23.02.02

Wojtuń, M. (2017). W stronę demokracji administracyjnej - partycypacja w postępowaniu administracyjnym we Francji [Towards administrative democracy - participation in administrative proceedings in France]. In Z. Kmieciak (Ed.) Partycypacja w postepowaniu administracyjnym. W kierunku uspotecznienia interesu prawnego [Participation in Administrative Proceedings. Toward Socialization of Legal Interest] (pp. 93-111). Warszawa, Poland: Wolters Kluwer. https://doi.org/10.17951/sil.2014.22.0.447

Zimmermann, J. (Ed.) (2019a). Integralność prawa administracyjnego. Perspektywa polska [Integrity of Administrative Law. Polish Perspective]. Warszawa, Poland: Wolters Kluwer.

Zimmermann, J. (Ed.) (2019b). Integrity of Administrative Law. Polish Perspective. Warszawa, Poland: Wolters Kluwer.

\section{Legal sources:}

The Constitution of the Republic of Croatia, Official Gazette No. 56/90, 135/97, 08/98, 113/00, 124/00, 28/01, 41/01, 55/01, 76/10, 85/10, 05/14

Treaty on European Union, Consolidated version, Official Journal C 326, https:// eur-lex.europa.eu/legal-content/EN/TXT/?uri=CELEX\%3A12012M\%2FTXT

Treaty on the Functioning of the European Union, Official Journal C 326, https:// eur-lex.europa.eu/legal-content/EN/TXT/?uri=CELEX\%3A12012M\%2FTXT 


\section{THE ADMINISTRATIVE STATE IN POLAND BEFORE AND AFTER THE EUROPEAN UNION ACCESSION}

\section{Summary}

The article identifies and describes the fundamental dimensions and elements of the Polish administrative state before and after the accession of Poland to the European Union, beginning with the critical question of how to preserve the status of a state in a supra-state organization. The authors explain the essence of the European Union, or Europeanization, in the field of Polish administration and administrative law. Analysis of the Europeanization of Polish administrative law is focused on its basic aspects grouped under six beadings: sources, cooperation, paradigm (constitutionalization), administrative democracy, scope and depth, and outcomes. Separate attention is given to the notion of public administration, as the widely applied definition of the concept framed by Jan Boc became obsolete after accession to the European Union and required transformation and extension. With language being a key feature of public administration, the text points to the post-accession impact of the English language on Polish administration and administrative law. The article concludes with outcomes of Europeanization on the gestalt of the administrative state in Poland. The general outcome stresses that Polish administration and administrative law operate not only within the context of the Polish state and Polish law, but increasingly within a supra-state European administrative framework and European legal space and European public law.

Keywords: state, administration, administrative law, accession, European Union, Europeanization 


\section{UPRAVNA DRŽAVA U POLJSKOJ PRIJE I POSLIJE PRIDRUŽIVANJA EUROPSKOJ UNIJI}

\section{Sažetak}

$U$ radu se utvrduju $i$ opisuju osnovne dimenzije $i$ elementi upravne države $u$ Poliskoj prije i poslije pridruživanja Europskoj uniji počevši od ključnog pitanja kako očuvati status države u naddržavnoj organizaciji. Autori objašnjavaju bit Europske unije, odnosno europeizaciju poljske javne uprave i upravnog prava. Analizira se šest osnovnib komponenti europeizacije poljskog upravnog prava: izvori, suradnja, paradigma (konstitucionalizacija), demokratizacija, opseg $i$ dubina te dugoročni učinci europeizacije. Posebna se pažnja u radu posvećuje pojmu javne uprave jer je široko pribvaćena definicija tog pojma Jana Boća nakon pridruživanja Europskoj uniji postala zastarjela te traži preoblikovanje $i$ proširenje. S obzirom na to da je jezik ključna karakteristika javne uprave u radu se upućuje na utjecaj engleskog jezika na poljsku upravu i upravno pravo do kojeg je došlo poslije pridruživanja Uniji. Rad završava pregledom dugoročnib učinaka europeizacije na karakter upravne države u Poljskoj. Utvrđeno je da poljska javna uprava i upravno pravo djeluju ne samo u kontekstu poljske države i poljskog prava, nego sve više i unutar europskoga naddržavnog upravnog okvira te europskog pravnog prostora $i$ europskog javnog prava.

Ključne riječi: država, uprava, upravno pravo, pridruživanje, Europska unija, europeizacija 